\title{
eNOS Glu298Asp Polymorphism and Endothelial Dysfunction in Patients with and without End-stage Renal Disease
}

\author{
Nevin İlhan ${ }^{1}$, Kadir Ateş ${ }^{1}$, Necip İlhan ${ }^{1}$, Dilara Kaman ${ }^{1}$, Hüseyin Çeliker ${ }^{2}$

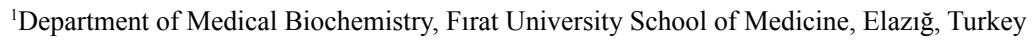 \\ ${ }^{2}$ Department of Nephrology, Firat University Hospital, Elazığ, Turkey
}

Background: Chronic kidney diseases are known to influence nitric oxide metabolites (NOx) and asymmetric dimethylarginine (ADMA), though the exact mechanism is still poorly understood.

Aims: The purpose of the present study was to examine eNOS Glu298Asp gene polymorphism, plasma NOx and ADMA concentration in subjects with and without End-stage Renal Disease.

Study Design: Case-control study.

Methods: In this study, genotype distributions of Glu298Asp in exon 7 of the eNOS gene polymorphisms in 130 hemodialysis and 64 peritoneal dialysis patients were compared with 92 controls. NOx was measured by using the Griess reaction while arginine, ADMA and SDMA measurements were performed by HPLC. Genotyping for eNOS Glu298Asp polymorphism was detected with the polymerase chain reaction and/or polymerase chain reaction-restriction fragment length polymorphism (PCR-RFLP) technique.

Results: When the genotype frequencies of TT and GT genes were compared between both groups, there was no detected statistically important difference, eventhough a TT genotype frequency was 27 (20.8\%) versus $17(26.6 \%)$, GT heterozygote genotype frequency was $52(40 \%)$ versus $22(34.4 \%)$, and GG homozygote genotype frequency was $51(39.2 \%)$ versus $25(39.1 \%)$, respectively ( $>0.05)$. NOx, SDMA and ADMA concentrations were significantly elevated in subjects with hemodialysis patients as compared to their corresponding controls. Whereas nitrite was found to be significantly decreased in the patient with peritoneal dialysis. Conclusion: Not observed any connection between the Glu298Asp polymorphism in the eNOS gene and end-stage Renal Diseases in our study population under different dialysis treatments. However, higher ADMA and SDMA concentrations in subjects with ESRD support the existing hypothesis that NOx overproduction affects endothelial dysfunction. Thus, the reduction of ADMA and SDMA concentrations might play a protective role in ESRD patients.

Keywords: eNOS Glu298Asp, endothelial dysfunction, end-stage renal disease
Endothelial dysfunction and impaired regulation of nitric oxide (NO) system has emerged as the characteristics of chronic kidney diseases (CKD). The accumulation of asymmetric dimethylarginine (ADMA) plays a role in the impairment regulation of NO in these patients; however, the mechanism of these disorders is not clear. Increased levels of ADMA and NO bioavailability reduction play a vital role in the pathogenesis of many diseases like coronary atherosclerosis, CKD or dia- betes mellitus (1). Morever, accumulation of reactive oxygen species by the increasing NO leads to atherogenesis, hence a over production may also damage cells and tissues (2).

Oxidative stress has a very considerable role in the endothelial dysfunction, vascular damage and in the development of cardiovascular diseases. Some of these mechanisms are associated with the oxidative inactivation of $\mathrm{NO}$ production and the inhibition of $\mathrm{NO}$ synthase activity by free oxygen radicals

This study was presented at the $3^{\text {rd }}$ International Congress of Molecular Medicine, 5-8 May 2009, İstanbul, Turkey.

Address for Correspondence: Dr. Nevin İlhan, Department of Medical Biochemistry, Furat University School of Medicine, Elazığ, Turkey Phone: +90 5334147023 e-mail: drnilhan@yahoo.com

Received: 1 July 2014 Accepted: 20 October 2015 • DOI: 10.5152/balkanmedj.2016.16566

Available at www.balkanmedicaljournal.org

İlhan N, Ateş K, İlhan N, Kaman D, Çeliker H. eNOS Glu298Asp polymorphism and endothelial dysfunction in patients with and without end-stage renal disease. 
(3). Earlier studies have shown oxidant/antioxidant imbalance -elevated oxidative damage, reduced antioxidant levels and impaired NO bioactivity- in patients of hemodialysis, resulting in high malondialdehyde levels demonstrated as an indicator of lipid peroxidation $(4,5)$.

Nitric oxide, has a crucial role in the vascular homeostasis, regulation of blood flow and blood pressure, is synthesized in the endothelium by a constutive endothelial nitric oxide synthase (eNOS) enzyme. NO production may be effected by several allelic variants of the eNOS gene. eNOS gene polymorphism occurs when a guanine turns into thymidine substitution at position 894 within the exon 7, leads to a change from glutamic acid to aspartic acid at codon 298 (Glu298Asp) in the eNOS protein, is associated with decreased enzyme activity of eNOS and basal NO production, and has been determined to be clinically important for several diseases $(6,7)$. Some reasons like decreased NO synthesis, eNOS gene polymorphisms, and/or arginine defiency may cause increased circulating NOS inhibitors levels, which contributes to an increase in arterial pressure or intraglomerular hypertension in CKD patients (8). NO synthesis is inhibited by the dimethylarginines (DMAs), which are accumulated in plasma during CKD (9). Many studies have shown that the increased level of asymmetric dimethylarginine (ADMA), leads to development of endothelial dysfunction via decreased NO formation in various diseases. Therefore, it is expressed that increased ADMA levels are estimate of future cardiovascular events and overall mortality rate in CKD (10-12).

The stereo-isomer of ADMA (SDMA) is eliminated almost substantially by urinary excretion; whereas main elemination pathway of ADMA is enzymatic degradation by dimethylarginine dimethylaminohydrolase (DDAH) enzymes. DDAH activity is play a role in regulation of plasma ADMA levels, provides of ADMA removal, and contributes to the pathogenesis of endothelial dysfunction in CKD (13). Today, as a uremia toxin, ADMA is gathered in End-stage Renal Disease (ESRD) patients and increased plasma ADMA concentration is interacted with oxidative stress. Plasma ADMA accumulation has been identified as a predictive factor for Cardiovascular Diseases (CVDs) and causes of mortality associated with ESRD. However, it is still unknown whether the eNOS gene polymorphisms would mediate the cardiovascular prognosis of ESRD patients. Various polymorphisms of eNOS gene were identified. The eNOS gene, a common variant modifies its coding sequence for Glu298Asp (rs1799983). This variant has been found to be connected with hypertension, diabetic nephropathy, ESRD and nondiabetic ESRD (14-16). Accordingly, the increase of plasma ADMA levels during CKD has suspected to be a factor in the progression of CKD (17-20).

We examined the relationship between the eNOS Glu298Asp gene polymorphism by different dialysis treatments and whether it depends of DMA levels to determine vascular damage in ESRD patients. Although there are reports of various countries, there is lack of data from Turkey in the literature. Therefore, this is the first comprehensive ESRD study evaluating a combination of both genetic and biochemical parameters carried out in Turkey.

\section{MATERIALS AND METHODS}

\section{Patients}

This study was performed on one hundred ninety four dialysis patients (average age was $49.54 \pm 18.82$ years) that underwent hemodialysis or peritoneal dialysis in the Firat University Hospital Hemodialysis Unit and Özel Çağrı Dialysis Center (Elazığ, Turkey) between September 2007 and February 2009. One hundred thirty patients (71 women, 59 men) with CKD undergoing HD and 64 patients (28 women, 36 men) with chronic ambulatory peritoneal dialysis (CAPD) were comprised in this study. Patients with overt infection were excluded from the study. Ninety two age- matched (average age was $51.15 \pm 11.96$ years) healthy volunteers ( 49 men and 43 women) considered as control group were obviously healthy and free from systemic illness such as CVD, diabetes mellitus or renal disease and they did not use any medication. Ethic approval for the study was given by the Firat University Local Ethical Committee (number 02, 22.02.2007). All participants were informed about the study and signed the consent form before the start of the study.

For dialysis-treated patients, sampling was performed before the dialysis sessions. Controls were fasted for $10 \mathrm{~h}$ before blood sampling. Blood samples of all participants were transferred to plastic tubes with and without anticoagulant and centrifuged at $1200 \times \mathrm{g}$ for $15 \mathrm{~min}$ at $4^{\circ} \mathrm{C}$; their serum and plasma layers were portioned, and stored at $-80^{\circ} \mathrm{C}$ for the analysis of other parameters.

Serum glucose, total cholesterol, triglyceride (TG), high density lipoprotein- cholesterol (HDL-C), total protein, albumin, urea, uric acid, creatinine and serum electrolytes levels were evaluated by using standart process in the routine laboratory. The plasma malondialdehyde (MDA) levels were measured as an index of lipid peroxidation. Proteins in plasma samples were precipitated with acid, the samples were centrifuged at $4500 \mathrm{x}$ g for 5 minutes. Adding TBA reagent on supernatants was then incubated in a water bath at $90^{\circ} \mathrm{C}$ for $45 \mathrm{~min}$. After incubation, the TBAMDA adduct was extracted with isobutanol. Twenty microliters of supernatant (butanol phase) was taken and injected into the HPLC system. 1,1,3,3-tetraethoxypropane (TEP) was used as standard MDA and results were expressed as nanomoles per mililiter. 
The concentrations of plasma ADMA, SDMA and L-arginine were detected as o-phthaldialdehyde (OPA) derivatives by high-performance liquid chromatography (HPLC). These assays are require analytical differentiate ADMA and SDMA with high specificity reproducibility. Thus, which is the most appropriate test, high-performance liquid chromatography, was used in this study. Rest supine systolic and diastolic blood pressures were measured in each subject using a standard sphygmomanometer before the beginning of the vascular measurements.

The causes of chronic renal disease in patients included the following rates: chronic glomerular nephritis $(n=32)$, diabetic nephropathy $(\mathrm{n}=64)$, hypertensive nephropathy $(\mathrm{n}=31)$, polycystic kidney $(\mathrm{n}=3)$, nephrotic syndrome $(\mathrm{n}=6)$, amiloidoz $(\mathrm{n}=5)$, nephrolithiasis $(\mathrm{n}=8)$, alport syndrome $(\mathrm{n}=2)$, multiple myeloma $(\mathrm{n}=2)$, diabetes mellitus $(\mathrm{n}=3)$, and unknown cause $(\mathrm{n}=38)$. The diagnosis of cardiovascular complications was performed by echocardiography and electrocardiography. For treating hemodialysis patients, standard bicarbonate solution was used three times a week with semisynthetic membranes or $\mathrm{Cu}-$ prophan. The average urea and fractional urea clearance $(\mathrm{Kt} / \mathrm{V})$ in HD patients was $1.27 \pm 0.31$, while in CAPD patients was $1.68 \pm 0.34$ weekly. Some of the patients who has CAPD $(n=9)$ had a 24 hour urine volume $>200 \mathrm{~mL} /$ day, while all hemodialysis patients's daily urine output was $<200 \mathrm{~mL}$. All patients with oral or parenteral iron preparations according to the parameters of blood count, iron and erythropoietin; calcium carbonate, calcium acetate and active vitamin $\mathrm{D}_{3}$ according to the balance of calcium and phosphorus, statins according to lipid parameters, blood pressure and weight according to follow-ups were using antihypertensive and diuretic. The patients were use in the antihypertensive calcium channel blockers, ACE inhibitors, angiotensin receptor blockers and a lesser extent; $\beta$-blockers without intrinsic activity make use of semptomimetik.

\section{DNA isolation and quantitation}

DNA isolation was performed from two milliliters of whole blood by using commercially available genomic DNA purification kits (EZ-10 Spin Column Blood Genomic DNA Minipreps Kit, product code: BS484, Bio Basic Inc.; Ontario, Canada) following the manufacturer's instructions.

\section{Genotyping}

The specific genotype of the missense Glu298Asp variant was detected by polymerase chain reaction (PCR). The primers used for PCR amplification of Glu298Asp polymorphism were: sense 5=- AAG GCA GGA GAC AGT GGA TGG A-3 and antisense 5=- CCC AGT CAA TCC CTT TGG TGC TCA-3. PCR was performed in a total volume of $50 \mu \mathrm{L}$ containing 100 ng genomic DNA, $0.4 \mu \mathrm{mol}$ of each primer, Taq polymerase buffer $\left(2 \mathrm{mM} \mathrm{MgCl}_{2}\right)$ and $1 \mathrm{U}$ of Amplitaq DNA polymerase (Sigma-Aldrich Co.; St. Louis, MO, ABD). PCR amplification was performed in a programmable thermal cycler gradient PCR system (Bio-Rad Laboratories, ABD; Model: PTC-200 rev:D:A). The PCR amplification protocol was carried out for 35 cycles, each cycle comprising denaturation at $94^{\circ} \mathrm{C}$ for $30 \mathrm{~s}$, annealing at $61^{\circ} \mathrm{C}$ for $30 \mathrm{~s}$, extention at $72^{\circ} \mathrm{C}$ for $30 \mathrm{~s}$. The predenaturation stage was exercised at $94^{\circ} \mathrm{C}$ for $4 \mathrm{~min}$.

\section{Restriction analysis of Glu298Asp}

For restriction digestion, $25 \mu \mathrm{L}$ amplicon, $5 \mu \mathrm{L} 10 \mathrm{X}$ PCR buffer and 8 units of BanII enzyme (New England Biolabs, Cambridge, UK) in a total $50 \mu \mathrm{L}$ volume were used. Then, the samples were incubated for $5 \mathrm{~h}$ at $37^{\circ} \mathrm{C}$. The existence of $\mathrm{T}$ at nucleotide 894 which matches with Asp 298. The 248 base pair (bp) PCR product is cleaved into two fragments of 163 and $85 \mathrm{bp}$. For separating the digested fragments, $3 \%$ agarose gel was used and the base pairs detected by ethidiumbromide staining and direct visualization under ultraviolet light. To determine the molecular weight of bands, consisting of $100 \mathrm{bp}$ of DNA ladder was used (21) (Figure 1).

Plasma total nitrite levels were determined by spectrophotometrically with the Griess technique (22). All samples were initially deproteinized $\left(\mathrm{ZnSO}_{4}\right.$ and $\mathrm{NaOH}$ solution) before the assay. Copporized cadmium granules were added to each sample in order to convert nitrates into nitrites. Griess reagent was then added to supernatants. The mixture was incubated at room temperature for $30 \mathrm{~min}$ and the absorbance was read at $545 \mathrm{~nm}$ by a spectrophotometer (Ultraspect Plus, Pharmacia LKB Biochrom Ltd; Cambridge, UK). Results were stated as $\mu \mathrm{mol} / \mathrm{L}$. Measurement of the nitrite which is the last product

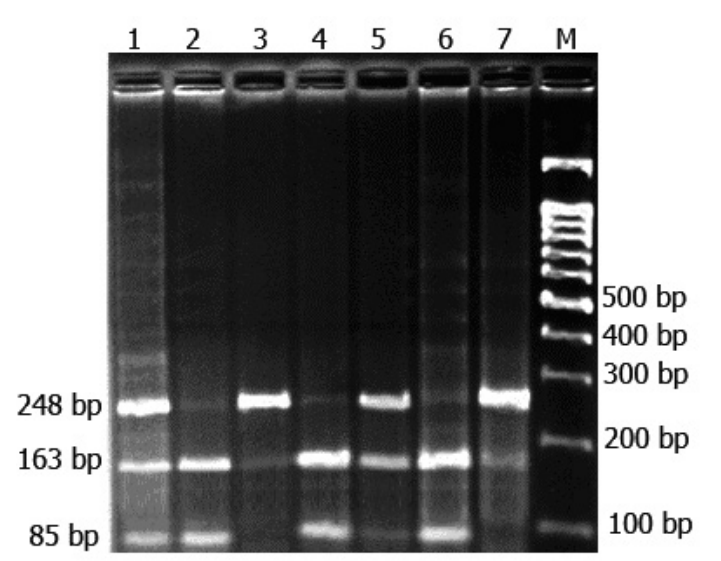

FIG. 1. Restriction band pattern of eNOS Glu298Asp gene polymorphism in the exon 7. Lane 1 and 5 showing the GT (Glu/Asp)heterozygotes bands at $248 \mathrm{bp}, 163 \mathrm{bp}$ and $85 \mathrm{bp}$. Lanes 2, 4 and 6 showing the GG (wild type)- homozygotes bands at $163 \mathrm{bp}$ and $85 \mathrm{bp}$. Lanes 3 and 7 showing the TT (mutant)-homozygous bands at $248 \mathrm{bp}$. $\mathrm{M}, \mathrm{DNA}$ molecular weight marker (100 bp ladder). 
of the NO radical in samples was most often used as a index for the production of NO (NOx).

All calculations were performed using SPSS 21.0 software package programme. Data are expressed as mean $\pm \mathrm{SD}$, percentage frequency or median, as appropriate. Hardy-Weinberg equilibrium was tested by Chi-square $\left(\chi^{2}\right)$ for the frequencies of the eNOS genotypes across all subjects. Chi-square analysis and Fisher's exact test were used to assess genotype distributions and the allele ratios in the cases and controls, whichever appropriate. General characteristic and genotypes were compared using One-way analysis of variance (ANOVA) test with the least significant difference (LSD) post-hoc comparison. LSD post-hoc test helps us to determine the differences between the groups in the presence of more than two groups. This method has been preffered because of the different number of genotypes frequencies of glu298asp polymorphism (not equal to the number of samples) in the treated groups with different dialysis procedures and controls, it is widely used by us. Odds ratios were calculated two tailed $\mathrm{p}$ values and $95 \%$ confidence intervals (CI). The Student's t-test was used to compare the differences of biochemical parameters between the two groups. $P$ values of $<0.05$ were considered significant.

\section{RESULTS}

\section{Characteristics of the study participants}

There was no significant differences among the patients and their controls, being homogeneous for social and demographics data $(\mathrm{p}>0.05)$. Age, sex, dialysis duration and other biochemical parameters of both groups are showed in Table 1. Statistically significant difference wasn't found between the two groups in relation to sex, age, mean DBP, total cholesterol, LDL-C, total protein and uric acid levels, while the mean of glucose, SBP, triglyceride, albumin, urea, creatinine and MDA levels were notably higher in all dialysis-treated group than controls. However the mean of HDL-cholesterol levels was notably higher in the control group. Unlike creatinine, renal function parameters such as urea and uric acid were significantly higher in HD patients group than in the group of CAPD. In the total ESRD group, urea concentration was approximately four times higher $(\mathrm{p}<0.001)$, whereas creatinine concentration was about eight-fold higher $(p<0.001)$ than controls.

Both DMAs plasma concentrations were very low in healthy controls $\quad(\mathrm{ADMA}=1.31 \pm 0.44 \mu \mathrm{mol} / \mathrm{L} ; \quad \mathrm{SDMA}=1.44 \pm 0.16$ $\mu \mathrm{mol} / \mathrm{L}$ ). Compared to controls, the concentration of SDMA in the HD group was about three times higher $(\mathrm{p}<0.001)$, but the concentration of ADMA was only $44 \%$ higher $(p<0.001)$. Both DMAs concentrations have increased considerably in the HD group (ADMA: $2.98 \pm 1.04 \mu \mathrm{mol} / \mathrm{L}$, SDMA: $3.78 \pm 0.72$ $\mu \mathrm{mol} / \mathrm{L}$ ). The plasma concentrations of DMAs were slightly higher in CAPD group compared to controls $(\mathrm{p}<0.05)$. Plasma arginine concentrations changed according to type of dialysis: control: $30.63 \pm 14.98$, HD: $24.25 \pm 10.54$, CAPD: $32.98 \pm 12.10$ $\mu \mathrm{mol} / \mathrm{L}$. This reduction in the concentration of arginine fell below normal values after hemodialysis, could not be determined CAPD. However, in terms of similarity to the control group; the molar ratio of SDMA/arginine was found to be more effective than the ratio of ADMA/arginine.

The levels of L-arginine for HD patients were notably lower than in the CAPD $(p=0.043)$. The ratio of L-arginine and ADMA for HD patients were also crucially lower than both CAPD patients and also the controls $(p=0.001)$. The SDMA, ADMA and ratio of ADMA/SDMA were considerably different between the CAPD and HD patients $(\mathrm{p}<0.001)$. In HD patients, reduction of L-arginine/ADMA rates seems more logical than ADMA concentration in terms of the hemodialysis indication.

\section{Glu298Asp polymorphism and ESRD}

The genotype and allele frequencies of the Glu298Asp polymorphism among ESRD patients and controls were shown in Table 2. The G allele frequency was found to be 0.63 and 0.418 , and the $\mathrm{T}$ allele frequency was found to be 0.37 and 0.582 respectively among healthy controls and ESRD patients. T allele percentage was lower while the percentage of $\mathrm{G}$ allele was higher in the control group. However, this was not statistically significant $\left(\chi^{2}\right.$ test $=1.19$, Degree of free$\mathrm{dom}=1, \mathrm{p}=0.315$ ). The frequencies for the three genotypes in patients were as follows: homozygous wild-type G/G - 51 of $130(39.2 \%)$, heterozygous genotype $\mathrm{G} / \mathrm{T}-52$ of $130(40 \%)$ and homozygous mutant T/T - 27 of $130(20.8 \%)$ in hemodialysis patients; G/G - 25 of 64 (39.1\%), G/T - 22 of 64 (34.4\%) and T/T - 17 of 64 (26.6\%) in CAPD patients; G/G - 76 of 194 (39.2\%), G/T - 74 of 194 (38.1\%) and T/T - 44 of $194(22.7 \%)$ in total ESRD patients $\left(\chi^{2}\right.$ test $=1.5$, Degree of freedom $=1, p=0.472$ ). Hardy-Weinberg equilibrium analysis indicated that the genotype distribution for the eNOS gene (Glu298Asp) in these population were in accordance with Hardy-Weinberg equilibrium.

\section{eNOS Glu298Asp polymorphism and NOx, arginine, SDMA, ADMA levels}

Compared with controls, HD-treated patients showed notably higher total ADMA levels. The accumulation of ADMA in ESRD was also confirmed by this study. CAPDtreated patients showed remarkably lower ADMA levels than patients treated with HD. For the progression of 
TABLE 1. Characteristics of ESRD patients and age- and sex-matched healthy controls

\begin{tabular}{|c|c|c|c|c|c|}
\hline & \multicolumn{3}{|c|}{ All ESRD patients ( $\mathrm{n}=194)$} & \multirow{2}{*}{\multicolumn{2}{|c|}{$\begin{array}{c}\mathrm{p} \text { value } \\
\text { (compared to the control) }\end{array}$}} \\
\hline & $\begin{array}{l}\text { Healthy Control } \\
\qquad(\mathrm{n}=92)\end{array}$ & $\begin{array}{l}\text { Hemodialysis Patients } \\
\qquad(\mathrm{n}=130)\end{array}$ & $\begin{array}{l}\text { CAPD Patients } \\
\quad(\mathrm{n}=64)\end{array}$ & & \\
\hline \multirow[t]{2}{*}{ Age (y) } & \multirow[t]{2}{*}{$51.15 \pm 11.96$} & \multicolumn{2}{|c|}{$49.54 \pm 18.82$} & & \\
\hline & & $50.44 \pm 21.02$ & $48.17 \pm 14.93$ & & \\
\hline \multirow[t]{2}{*}{$\operatorname{Sex}(M / F)$} & \multirow[t]{2}{*}{$48 / 44$} & \multicolumn{2}{|c|}{$194(97 \mathrm{M} / 97 \mathrm{~F})$} & & \\
\hline & & $60 \mathrm{M} / 70 \mathrm{~F}$ & $37 \mathrm{M} / 27 \mathrm{~F}$ & & \\
\hline Dialysis Duration (months) & \multirow{2}{*}{ No } & \multicolumn{2}{|c|}{$34(8-211)$} & & \\
\hline Median (min-max) & & $22(8-211)$ & $46(12-106)$ & & \\
\hline \multirow[t]{2}{*}{ Glucose (mg/dL) } & \multirow[t]{2}{*}{$95.22 \pm 13.06$} & \multicolumn{2}{|c|}{$126.18 \pm 82.04$} & \multicolumn{2}{|c|}{$<0.001$} \\
\hline & & $132.38 \pm 90.87$ & $113.58 \pm 58.94$ & $<0.001$ & $<0.009$ \\
\hline \multirow[t]{2}{*}{$\mathrm{SBP}(\mathrm{mm} \mathrm{Hg})$} & \multirow[t]{2}{*}{$120.0 \pm 10.0$} & \multicolumn{2}{|c|}{$134.49 \pm 29.23$} & \multicolumn{2}{|c|}{$<0.001$} \\
\hline & & $131.80 \pm 26.83$ & $140.17 \pm 34.04$ & $=0.004$ & $<0.001$ \\
\hline \multirow[t]{2}{*}{$\mathrm{DBP}(\mathrm{mm} \mathrm{Hg})$} & \multirow[t]{2}{*}{$70.0 \pm 5.0$} & \multicolumn{2}{|c|}{$83.21 \pm 17.50$} & & \\
\hline & & $80.08 \pm 15.68$ & $89.83 \pm 19.35$ & & $<0.001$ \\
\hline \multirow[t]{2}{*}{ T-cholesterol (mg/dL) } & \multirow[t]{2}{*}{$203.78 \pm 15.53$} & \multicolumn{2}{|c|}{$195.01 \pm 55.05$} & & \\
\hline & & $189.83 \pm 58.96$ & $203.16 \pm 47.58$ & $=0.038$ & \\
\hline \multirow[t]{2}{*}{$\mathrm{HDL}-\mathrm{C}(\mathrm{mg} / \mathrm{dL})$} & \multirow[t]{2}{*}{$57.84 \pm 8.55$} & \multicolumn{2}{|c|}{$39.99 \pm 10.91$} & \multicolumn{2}{|c|}{$<0.001$} \\
\hline & & $40.06 \pm 11.44$ & $39.53 \pm 6.72$ & $<0.001$ & $<0.001$ \\
\hline \multirow[t]{2}{*}{ LDL-C (mg/dL) } & $118.72 \pm 16.67$ & & & & \\
\hline & & $117.71 \pm 43.80$ & $134.50 \pm 37.11$ & & $<0.001$ \\
\hline $\mathrm{TG}(\mathrm{mg} / \mathrm{dL})$ & $99.27 \pm 43.92$ & & & & \\
\hline & & $188.26 \pm 125.88$ & $190.50 \pm 116.82$ & $<0.001$ & $<0.001$ \\
\hline Total protein $(\mathrm{g} / \mathrm{dL})$ & $6.93 \pm 0.45$ & & & & \\
\hline & & $6.91 \pm 0.86$ & $7.03 \pm 0.69$ & & \\
\hline Albumin $(\mathrm{g} / \mathrm{dL})$ & $3.37 \pm 0.64$ & & & & \\
\hline & & $3.70 \pm 0.65$ & $3.69 \pm 0.51$ & $<0.001$ & $<0.002$ \\
\hline Urea $(\mathrm{mg} / \mathrm{dL})$ & $36.13 \pm 6.74$ & & & & \\
\hline & & $155.94 \pm 61.16$ & $131.75 \pm 41.27$ & $<0.001$ & $<0.001$ \\
\hline Creatinine $(\mathrm{mg} / \mathrm{dL})$ & $1.13 \pm 0.20$ & & & & \\
\hline & & $7.98 \pm 2.55$ & $9.49 \pm 2.88$ & $<0.001$ & $<0.001$ \\
\hline Uric acid $(\mathrm{mg} / \mathrm{dL})$ & $6.32 \pm 1.59$ & & & & \\
\hline & & $6.57 \pm 1.95$ & $6.06 \pm 1.15$ & & \\
\hline $\operatorname{MDA}(\mathrm{nmol} / \mathrm{mL})$ & $1.21 \pm 0.38$ & & & & \\
\hline & & $1.76 \pm 1.33$ & $1.56 \pm 0.36$ & $<0.001$ & \\
\hline
\end{tabular}

Data are reported as mean $\pm \mathrm{SD}$

$\mathrm{p}$ values were obtained by the unpaired Student's t, Mann-Whitney U, or $\chi 2$-test, as appropriate.

n: number of individuals; M: male; F: female; SBP: systolic blood pressure; DBP: diastolic blood pressure; ESRD: end-stage renal disease; CAPD: chronic ambulatory peritoneal dialysis; HDL-C: high-density lipoprotein cholesterol; LDL-C: low-density lipoprotein cholesterol; TG: triglyceride; MDA: malondialdehyde

endothelial dysfunction in ESRD patients, ADMA accumulation may be a risk factor. According to HD patients with TT genotype, GT genotype was significantly higher in arginine and ADMA levels $(\mathrm{p}<0.05)$. NOx levels in HD patients with GG genotype were significantly lower than TT genotype $(p<0.05)$. SDMA concentrations were nota- 
TABLE 2. Glu298Asp Genotype Distribution and G and T Allele Frequency in groups of control, HD, CAPD and ESRD patients

\begin{tabular}{|c|c|c|c|c|c|c|c|c|}
\hline Genotype & $\begin{array}{l}\text { Control } \\
\mathrm{n}(\%)\end{array}$ & $\begin{array}{c}\text { ESRD Patients } \\
\text { n (\%) }\end{array}$ & $\begin{array}{c}\chi^{2} \\
\text { p value }\end{array}$ & $\begin{array}{l}\text { Odds ratio } \\
(95 \% \mathrm{CI})\end{array}$ & $\begin{array}{c}\text { HD Patients } \\
\mathrm{n}(\%)\end{array}$ & $\begin{array}{c}\text { CAPD Patients } \\
\text { n (\%) }\end{array}$ & $\begin{array}{c}\chi^{2} \\
\text { p value }\end{array}$ & $\begin{array}{l}\text { Odds ratio } \\
(95 \% \mathrm{CI})\end{array}$ \\
\hline GG & $43(46.7)$ & $76(39.2)$ & \multirow{3}{*}{$\begin{array}{c}\chi 2=1.5 \\
p=0.472\end{array}$} & \multirow{3}{*}{$\begin{array}{c}0.455 \\
(0.379-0.530)\end{array}$} & $51(39.2)$ & $25(39.1)$ & \multirow{3}{*}{$\begin{array}{l}\chi 2=1.35 \\
\mathrm{p}=0.641\end{array}$} & \multirow{3}{*}{$\begin{array}{c}0.598 \\
(0.507-0.689)\end{array}$} \\
\hline GT & $30(32.6)$ & $74(38.1)$ & & & $52(40.0)$ & $22(34.4)$ & & \\
\hline TT & $19(20.7)$ & 44 (22.7) & & & $27(20.8)$ & $17(26.6)$ & & \\
\hline Allele & $\begin{array}{c}\text { Control } \\
\mathrm{n}(\%)\end{array}$ & $\begin{array}{c}\text { ESRD Patients } \\
\text { n (\%) }\end{array}$ & $\begin{array}{c}\chi^{2} \\
\mathrm{p} \text { value }\end{array}$ & $\begin{array}{l}\text { Odds ratio } \\
(95 \% \mathrm{CI})\end{array}$ & $\begin{array}{c}\text { HD Patients } \\
\mathrm{n}(\%)\end{array}$ & $\begin{array}{c}\text { CAPD Patients } \\
\text { n }(\%)\end{array}$ & $\begin{array}{c}\chi^{2} \\
\text { p value }\end{array}$ & $\begin{array}{l}\text { Odds ratio } \\
(95 \% \mathrm{CI})\end{array}$ \\
\hline G & $116(62.9)$ & $162(41.8)$ & $\chi 2=1.19$ & 0.328 & $107(41.2)$ & $57(44.8)$ & $\chi 2=1.35$ & 0.572 \\
\hline $\mathrm{T}$ & $68(37.1)$ & $226(58.2)$ & $\mathrm{p}=0.315$ & $(0.267-0.368)$ & $153(58.8)$ & $71(55.2)$ & $\mathrm{p}=0.502$ & $(0.507-0.637)$ \\
\hline
\end{tabular}

Genotype and allele frequencies are shown as number (\%).

$\mathrm{p}$ values were obtained using the $\chi 2$ or Fisher's exact test, as appropriate. Odds ratios (ORs) with $95 \%$ confidence intervals (95\% CI) were obtained by logistic regression analysis. Multivariate logistic regression analysis was carried out for comparisons between total ESRD, HD and CAPD patients vs. healthy controls.

n: number of individuals; HD: hemodialysis; CAPD: chronic ambulatory peritoneal dialysis; ESRD: end-stage renal disease; CI: confidence intervals

TABLE 3. Nitric oxide, arginine, SDMA and ADMA levels according to the eNOS Glu298Asp genotype distribution in dialysis patients and controls

\begin{tabular}{|c|c|c|c|c|c|c|c|c|c|}
\hline & \multicolumn{3}{|c|}{ Control } & \multicolumn{3}{|c|}{ Hemodialysis Patients } & \multicolumn{3}{|c|}{ CAPD Patients } \\
\hline & $\begin{array}{c}\text { Glu/Glu } \\
\text { (GG) }\end{array}$ & $\begin{array}{c}\text { Glu/Asp } \\
\text { (GT) }\end{array}$ & $\begin{array}{c}\text { Asp/Asp } \\
\text { (TT) }\end{array}$ & $\begin{array}{c}\text { Glu/Glu } \\
\text { (GG) }\end{array}$ & $\begin{array}{c}\text { Glu/Asp } \\
\text { (GT) }\end{array}$ & $\begin{array}{c}\text { Asp/Asp } \\
\text { (TT) }\end{array}$ & $\begin{array}{c}\text { Glu/Glu } \\
\text { (GG) }\end{array}$ & $\begin{array}{c}\text { Glu/Asp } \\
\text { (GT) }\end{array}$ & $\begin{array}{c}\text { Asp/Asp } \\
\text { (TT) }\end{array}$ \\
\hline $\mathrm{NOx}(\mu \mathrm{mol} / \mathrm{L})$ & $635.6 \pm 134.2$ & $622.4 \pm 150.9$ & $653.9 \pm 169.5$ & $624.1 \pm 125.3^{*}$ & $664.3 \pm 140.9$ & $702.1 \pm 161.5$ & $549.4 \pm 94.5$ & $599.1 \pm 206.7$ & $515.3 \pm 72.0$ \\
\hline Arginine $(\mu \mathrm{mol} / \mathrm{L})$ & $30.2 \pm 15.43$ & $30.6 \pm 14.3$ & $31.7 \pm 15.8$ & $23.3 \pm 9.6$ & $26.7 \pm 11.98^{*}$ & $21.27 \pm 8.26$ & $33.2 \pm 12.8$ & $35.8 \pm 10.9$ & $28.9 \pm 12.9$ \\
\hline $\operatorname{SDMA}(\mu \mathrm{mol} / \mathrm{L})$ & $1.46 \pm .13$ & $1.41 \pm .20$ & $1.43 \pm .14$ & $3.87 \pm 0.7$ & $3.8 \pm 0.8$ & $3.55 \pm 0.48$ & $1.63 \pm 0.12$ & $1.59 \pm 0.17^{*}$ & $1.69 \pm 0.17$ \\
\hline $\mathrm{ADMA}(\mu \mathrm{mol} / \mathrm{L})$ & $1.40 \pm .46$ & $1.24 \pm .43$ & $1.23 \pm .36$ & $3.0 \pm 1.14$ & $3.15 \pm 1.05^{*}$ & $2.6 \pm 0.72$ & $1.6 \pm 0.49$ & $1.68 \pm 0.49$ & $1.78 \pm 0.49$ \\
\hline
\end{tabular}

Table 3 shows the frequencies of the eNOS Glu298Asp genotype.

Values present as mean \pm standard deviations, ${ }^{*} \mathrm{p}<0.05$, compared to Asp/Asp by a one-way ANOVA (LSD post-hoc comparison). Significances between genotype distributions in hemodialysis patients and CAPD patients are indicated by the stars on the right side. Stars indicate increased or decreased values.

Enos: endothelial NO synthase; ADMA: asymmetric dimethylarginine; SDMA: symmetric dimethylarginine; NOx: index of plasma total nitrite concentrations; CAPD: chronic ambulatory peritoneal dialysis

bly lower in the GT genotype groups according to the TT genotype groups in CAPD patients $(p<0.05)$ (Table 3 ). Although mean SDMA and ADMA concentration were higher in ESRD patients with HD- and CAPD-treated patients $(p<0.001$ and $p<0.05$, respectively) compared to controls, there were no significantly different according to their genotype in the hemodialysis and CAPD patient groups (Tukey HSD comparison).

\section{DISCUSSION}

Genetic studies associated with CKD can help to forecast the identification and progressing of this disease. Due to decreased activity of nitric oxide has been accelerated renal damage and progression of CKD, evaluation of eNOS gene polymorphisms can provide information about the sensitivity of CKD and the development of ESRD. Our study was designed to evaluate if there is any relationship between the eNOS gene polymorphism and endothelial-related biochemical parameters with different dialysis therapy in ESRD patients. Consequently, no associations between the Glu298Asp polymorphisms in the eNOS gene and dialysis patients with
ESRD on dialysis were observed. In fact, with many studies reporting conflicting results, the progress or development of kidney disease and the influence of dialysis has proven to be a challenging field of investigation in evaluating the role of eNOS polymorphisms.

The remerkable points of the study are as follows:

(1) SDMA and ADMA are accumulated in ESRD patients; (2) ADMA levels are considerably lower in CAPD-treated patients than in patients treated with HD; (3) the eNOSGlu298Asp gene polymorphism was not associated with ESRD; (4) NOx levels were higher in HD-treated patients. These may be helpful to assess the efficacy of treatment.

There is strong evidence suggesting a genetic basis for ESRD. Many factors including genetic factors have been well demonstrated for risk of vascular complications in patients with ESRD, even if the certain mechanism of genetic contributions was not fully established yet (19,23-25). The information obtained from last researches put forward that NO mediates the function of endothelium-dependent vasodilation which is considerable in vascular function disorders (23). Decreased levels of NO bioavailability and generation have been defined in 
ESRD patients as an indicator of endothelial dysfunction (26). Evidences of this polymorphism for relationship between impaired endothelial function and a decrease in enzymatic activity and production of nitric oxide and vascular-renal disease were reported in several studies (27-31). Afrasyap and Ozturk (21) could not find a relationship between nitric oxide levels and Glu298Asp polymorphism with coronary artery disease in the Turkish population. We did not find a significant association between Glu298Asp polymorphism and levels of nitric oxide in patients with ESRD in this study too. In our study, NOx and arginine values of all dialysis patient group compared with control group was lower, but no statistically significant difference. NOx levels were lower in peritoneal dialysis patients than in hemodialysis patients. In several studies were reported that the levels of plasma arginine are normal or low in patients with ESRD, in this study were found to be normal in CAPD patients and low in HD patients. Consistent with our results Schmidt et al. (32) demonstrated that NO production was low in ESRD patients on peritoneal dialysis. Hon et al. (33) demonstrated that HD led to a decrease in plasma NOx level, but Fayed et al. (34) suggested that plasma NO levels were increased in ureamic patients compared with normal controls, and hemodialysis led to further increases. Furthermore, the study of Rysz et al. (35) indicated that NO is released in the peripheral blood during HD, however this mechanism is still unclear. We considered that the high plasma NOx levels of HD patients may be involved in increased NO release from the peripheral blood and not failure to adequately cleaned of ADMA from plasma during $\mathrm{HD}$ when compared with CAPD patients. However, other factors unrelated to the dialysis procedure (for example, inflammation and oxidative stress) may contribute to the formation of uremia. The present study showed significant increase in the levels of MDA as markers of oxidative stress in ESRD patients with HD and CAPD in comparison to controls $(\mathrm{p}<0.001, \mathrm{p}<0.05$ respectively), also, there was significant increase in the levels of NOx in HD patients when compared with CAPD patients $(p<0.001)$. This increase in oxidative stress may contribute to endothelial dysfunction and reduced nitric oxide bioavailability. Furthermore, mean systolic and diastolic blood pressure were greather in HD and CAPD patients compared to controls, this increased blood pressure values were more significant in CAPD patients. These findings show that the suppression of NO production in CAPD patients is associated with increased blood pressure and in the rate of conversion of ADMA-arginine.

There are numerous reports on production of $\mathrm{NO}$ which contributes to dialysis membrane during HD. We thought that increased levels of NOx may be due to dialysis membranes in our study. In fact, Amore et al. (36) and Rysz et al. (35) showed that NO release and cytokine production by the biocompatible dialysis membrane polymethylmethacrylate is smaller than the bioincompatible membrane (cuprophan). They suggested that the extent of intradialytic NO generation was depend on dialysis membrane biocompatibility. On the other hand, Sasaki et al. (37) reported that there were no important differences between bioincompatible and biocompatible membrane with respect to plasma concentrations of NO.

The levels of NOx were found to be considerably lower in the GG genotype of hemodialysis patients as compared to TT genotype. This may have resulted as a consequence of increased occurrence of $\mathrm{T}$ allele or decreased ratio of plasma ADMA to arginine in hemodialysis patients. As well as the levels of the ADMA and arginine were notably decreased in hemodialysis patients with the TT genotype compared to the GT genotype is also help to explain this situation. Yilmaz et al. (38) reported that subjects with TT genotype were related to be prone to endothelial dysfunction due to low NOx synthesis. In this framework, our study confirmed that increased levels of NOx in hemodialysis patients with the TT genotype could protect to the endothelial dysfunction. Reports have suggested that the Glu298Asp polymorphism has an important mission in ESRD patients who have vascular disease $(30,39,40)$ while a recently published large meta-analysis gave negative results. Although some changes may be in terms of allele frequency for this polymorphism because of different ethnic groups, we found that the $\mathrm{T}$ allele distribution of this polymorphism similar to Caucasians (27) and other studies conducted in Turkey (21) and (41). Furthermore, several studies were shown that the eNOS gene could play a major role in the diabetic nephropathy and Glu298Asp polymorphisms in the eNOS gene were associated with ESRD susceptibility $(19,20,42)$.

Nitric oxide synthesis is inhibited by the DMAs in the plasma of patients suffering from ESRD. The concentrations of ADMA and possibly SDMA were enhanced in renal insufficiency (23). Plasma ADMA concentration increases with declining renal function, with reduced NO production and reduced expression of eNOS, and in case of inflammation and oxidative stress. Accumulation of ADMA has been associated with hypercholesterolaemia, hypertension, increased risk of cardiovascular events and death in patients with or without CKD. The pathophysiology of raised ADMA concentrations in ESRD could be multifactorial. ADMA, endogenous nitric oxide synthase inhibitor, has been associated with increased oxidative stress in endothelial cells and leads to endothelial dysfunction $(23,43,44)$. The endothelium dysfunction in ESRD patients has been shown by several clinical studies, however the main reason of this defect is not completely explained $(45,46)$. Kielstein et al. $(45)$ observed that concentrations of ADMA are higher in dialysis patients with clinically significant atherosclerosis than in non-atherosclerotic disease. This situation illustrates that ADMA may be major cardiovas- 
cular risk factor for end-stage renal disease. Hand et al. (46) reported that endothelial dysfunction was reversed after hemodialysis sessions.

Many studies have declarated that the DMAs concentrations are advanced in patients with uremic (47-49). In our study consisted of 92 healthy control and 194 renal diseases patients with two different dialysis procedures. With this large study groups, we observed SDMA's dependence of renal function: the SDMA concentration was roughly 2-fold in total ESRD patients and approximately 3 -fold higher in HD patients compared with healthy controls. In our study, the plasma ADMA and SDMA levels of the ESRD patients (including the hemodialysis and peritoneal dialysis group) are significantly higher than the control group $(p<0.001)$. It is suggested that the endothelial function disturbance in the patients of ESRD is related to the accumulation of the plasma DMAs. While compared two treatment methods for patients with ESRD, i.e., HD and CAPD, we found that CAPD-treated patients exhibited lower plasma ADMA concentrations than HD-treated patients. These different findings suggested the reason for this may be due to the differences in dialytic clearance of ADMA with the two treatment methods or the metabolism of ADMA. The peritoneal dialysis treatment can remove plasma ADMA partly. Although information on the impact of hemodialysis on ADMA plasma levels is controversial, hemodialysis seems not appropriate for the long-term disposal of DMA as confirmed in our HD group. Both DMAs are excreted through the kidneys and also ADMA is metabolized by dimethylaminohydrolase (DDAH). Therefore, in this study, higher levels of ADMA in HD and partially CAPD patients compared to control can be explained by impaired in this mechanism. But the specific mechanism of DMAs will be studied further. Increased NOx levels in our HD patients also have higher ADMA concentrations may be a backlash mechanism. But the specific mechanism of DMAs will be studied further. According to Vallance et al. (50), ESRD increased DMAs concentrations which cause an inhibition of NO synthesis after hypertension. In this study, we couldn't find any correlation between plasma ADMA levels not only systolic but also diastolic blood pressure in ESRD patient groups. A significant increase in systolic blood pressure levels was found in patients compared to control, whereas no significance in diastolic blood pressure levels in total ESRD and HD patients. SDMA concentrations in our patient groups correlated with only diastolic blood pressure (r:-0.198, $\mathrm{p}<0.013)$.

Asymmetric dimethylarginine accumulation in patients with endstage renal disease might explain endothelial dysfunction, because ADMA is eliminated during hemodialysis (43). Testa et al. (51) observed that having high ADMA levels as well as $\mathrm{T}$ allele carriers had a risk of cardiovascular death nearly three times higher than those having only one of these two risk fac- tors. This investigation has justification because production of NO in response to L-arginine is supressed in individuals who carry the T allele. ADMA, a naturally occurring analog of Larginine, has been identified as an endogenous competitive inhibitor of eNOS. ADMA most probably influences the underlying genetic defect in NO synthesis in individuals carrying the $\mathrm{T}$ allele. However, in our study, patients with ESRD undergoing hemodialysis with $\mathrm{T}$ allele when there is a significant increase in NOx levels $(p<0.05)$, ADMA and SDMA levels did not differ significantly as compared to those with the $G$ allele. The SDMA, ADMA and ratio of ADMA/SDMA were remarkably different between the CAPD and HD patients $(p<0.001)$. Plasma L-arginine levels in the HD patients were notably lower than in the CAPD patients $(\mathrm{p}=0.043)$. The $\mathrm{L}$-arginine/ADMA ratio was also significantly lower in the HD patients than the controls and the CAPD patients $(\mathrm{p}=0.001)$. Reduction of L-arginine/ ADMA ratio for HD patients seems to be more sensitive than ADMA concentration with regard to hemodialysis indication. In our study, there were no important differences among normal controls and total ESRD patients, with regard to plasma Larginine, NO levels and the ratio of ADMA/SDMA. According to our result, the low molar rate of ADMA/SDMA suggests the success of DDAH activity and hemodialysis treatment. Because Kielstein et al. (48) said that although ADMA is metabolized by DDAH, the excretion of SDMA stays unchanged; the high molar ratio of ADMA/SDMA suggests an impairment of DDAH activity excepts from subclinical renal impairment excludes. It was an explanation for the elevated ADMA.

The discrepancy in results depends on a plenty of reasons such as environmental factor, sample sizes, ethnic origin. In our study, the samples were collected from homogeneous populations. Not only patients but also control subjects were from the same geographically well-defined region (Elazığ city of Turkey). Physicians described the controls in a standardized way and controls were selected from individuals without vascular and renal disease. Nevertheless, our studies found no statistically significant difference in the haplotype frequencies in ESRD patients on dialysis compared with controls.

In conclusion, compared with healthy control group, ESRD patients had higher SBP, triglyceride, albumin, urea, creatinine, MDA, ADMA and SDMA levels (all $\mathrm{p}<0.05$ ). However, both genotype frequencies and allele distributions for the eNOS polymorphism were similar for two groups $(p>0.05)$ in our study. We noticed no major differences in haplotype distribution between groups ( $p>0.05$ ). eNOS Glu298Asp polymorphism may not be related to formation of the genetic component of chronic kidney disease that leads to ESRD, because there is no association between eNOS Glu298Asp polymorphism and ESRD. These findings are 
in agreement with the results of Marson et al. (52), who reported non-significant differences in the frequency of eNOS Glu298Asp genotypes in ESRD patients. Kidney disease is releated to elevated plasma of ADMA levels, decreased Arg/ ADMA ratio and polymorphisms of the eNOS gene. The lack of relationship between ADMA and other variables reinforces theory that ADMA is an independent predictor of cardiovascular risk and endothelial dysfunction.

Ethics Committee Approval: Ethics committee approval was received for this study from the ethics committee of Firat University Local Ethical Committee.

Informed Consent: Written informed consent was obtained the patients who participated in this study.

Peer-review: Externally peer-reviewed.

Author contributions: Concept - N.I.; Design - N.I., K.A., N.I.; Supervision - N.I., D.K., H.C.; Resource - N.I., K.A., H.C.; Materials - K.A., H.C.; Data Collection and/or Processing - N.I., K.A., D.K.; Analysis and\&/or Interpretation - N.I., K.A, N.I.; Literature Search - N.I., K.A., N.I.; Writing - N.I., K.A.; Critical Reviews - N.I., K.A.

Conflict of Interest: No conflict of interest was declared by the authors.

Financial Disclosure: This research was funded by Firat University Department of Scientific Research Projects.

\section{REFERENCES}

1. Nakamura T, Sato E, Fujiwara N, Kawagoe Y, Ueda Y, Suzuki T, et al. Positive association of serum levels of advanced glycation end products and high mobility group box-1 with asymmetric dimethylarginine in nondiabetic chronic kidney disease patients. Metabolism 2009;58:1624-8. [CrossRef]

2. Förstermann U. Oxidative stress in vascular disease: causes, defense mechanisms and potential therapies. Nat Clin Pract Cardiovasc Med 2008;5:338-49. [CrossRef]

3. Harrison DG. Cellular and molecular mechanisms of endothelial cell dysfunction. J Clin Invest 1997;100:2153-7. [CrossRef]

4. Jackson P, Loughrey CM, Lightbody JH, McNamee PT, Young IS. Effect of hemodialysis on total antioxidant capacity and serum antioxidants in patients with chronic renal failure. Clin Nephrol 1995;44:1135-8.

5. Daschner M, Lenhartz H, Botticher D, Schaefer F, Wollschlager M, Mehls O, et al. Influence of dialysis on plasma lipid peroxidation products and antioxidant levels. Kidney Int 1996;50:1268-72. [CrossRef]

6. Paradossi U, Ciofini E, Clerico A, Botto N, Biagini A, Colombo MG. Endothelial function and carotid intimamedia thickness in young healthy subjects among endothelial nitric oxide synthase Glu298Asp and T-786C polymorphisms. Stroke 2004;35:1305-9. [CrossRef]
7. Naber CK, Baumgart D, Altmann C, Siffert W, Erbel R, Heusch G. eNOS 894T allele and coronary blood flow at rest and during adenosineinduced hyperemia. Am J Physiol Heart Circ Physiol 2001;281:1908-12.

8. Hsu CN, Huang LT, Lau YT, Lin CY, Tain YL. The combined ratios of L-arginine and asymmetric and symmetric dimethylarginine as biomarkers in spontaneously hypertensive rats. Transl Res 2012;159:90-8. [CrossRef]

9. Busch M, Fleck C, Wolf G, Stein G. Asymmetrical (ADMA) and symmetrical dimethylarginine (SDMA) as potential risk factors for cardiovascular and renal outcome in chronic kidney disease - possible candidates for paradoxical epidemiology? Amino Acids 2006;30:225-32. [CrossRef]

10. Lu TM, Chung MY, Lin CC, Hsu CP, Lin SJ. Asymmetric dimethylarginine and clinical outcomes in chronic kidney disease. Clin J Am Soc Nephrol 2011;6:1566-72. [CrossRef]

11. Szlachcic A, Krzysiek-Maczka G, Pajdo R, Targosz A, Magierowski M, Jasnos K, et al. The Impact of Asymmetric Dimethylarginine (ADMA), the Endogenous Nitric Oxide (NO) Synthase Inhibitor, to the Pathogenesis of Gastric Mucosal Damage. Curr Pharm Des 2013;19:90-7. [CrossRef]

12. Young JM, Terrin N, Wang X, Greene T, Beck GJ, Kusek JW, et al. Asymmetric dimethylarginine and mortality in stages 3 to 4 chronic kidney disease. Clin J Am Soc Nephrol 2009;4:1115-20. [CrossRef]

13. Tatematsu S, Wakino S, Kanda T, Homma K, Yoshioka K, Hasegawa K, et al. Role of nitric oxide-producing and -degrading pathways in coronary endothelial dysfunction in chronic kidney disease. J Am Soc Nephrol 2007;18:741-9. [CrossRef]

14. Kerkeni M, Letaief A, Achour A, Miled A, Trivin F, Maaroufi K. Endothelial nitric oxide synthetase, methylenetetrahydrofolate reductase polymorphisms, and cardiovascular complications in Tunisian patients with nondiabetic renal disease. Clin Biochem 2009;42:958-64. [CrossRef]

15. Thaha M, Pranawa, Yogiantoro M, Sutjipto, Sunarjo, Tanimoto M, et al. Association of endothelial nitric oxide synthase Glu298Asp polymorphism with end-stage renal disease. Clin Nephrol 2008;70:144-54. [CrossRef]

16. Santos KG, Crispim D, Canani LH, Ferrugem PT, Gross JL, Roisenberg I. Association of eNOS gene polymorphisms with renal disease in Caucasians with type 2 diabetes. Diabetes Res Clin Pract 2011;91:353-62. [CrossRef]

17. Wang D, Strandgaard S, Borresen ML, Luo Z, Connors SG, Yan $\mathrm{Q}$, et al. Asymmetric dimethylarginine and lipid peroxidation products in early autosomal dominant polycystic kidney disease. Am J Kidney Dis 2008;51:184-91. [CrossRef]

18. Zhou TB, Yin SS. Association of endothelial nitric oxide synthase Glu298Asp gene polymorphism with the risk of end-stage renal disease. Ren Fail 2013;35:573-8. [CrossRef]

19. Zhou TB, Xu HL, Yin SS. Association between endothelial nitric oxide synthase Glu298Asp gene polymorphism and diabetic nephropathy susceptibility. Ren Fail 2013;35:173-8. [CrossRef]

20. Yun Z, Yu-Ping Y, Zong-Wu T, Yang S, Fang Y, Fang S. Association of endothelial nitric oxide synthase gene polymorphisms with end-stage renal disease: a systematic review and meta-analysis. Ren Fail 2014;36:987-93. [CrossRef] 
21. Afrasyap L, Ozturk G. NO level and endothelial NO synthase gene polymorphism (Glu298Asp) in the patients with coronary artery disease from the Turkish population. Acta Biochim Biophys Sin (Shanghai) 2004;36:661-6. [CrossRef]

22. Granger DL, Taintor RR, Boockvar KS, Hibbs JB Jr. Measurement of nitrate and nitrite in biological samples using nitrate reductase and Griess reaction. Methods Enzymol 1999;268:142-51. [CrossRef]

23. Aldámiz-Echevarría L, Andrade F. Asymmetric Dimethylarginine, Endothelial Dysfunction and Renal Disease. Int J Mol Sci 2012;13:11288-311. [CrossRef]

24. Zoccali C, Mallamaci F, Tripepi G. Novel cardiovascular risk factors in end-stage renal disease. J Am Soc Nephrol 2004;15:77-80. [CrossRef]

25. Tang FY, Liu FY, Xie XW. Association of angiotensin-converting enzyme and endothelial Nitric Oxide synthase gene polymorphisms with vascular disease in ESRD patients in a Chinese population. Mol Cell Biochem 2008;319:33-9. [CrossRef]

26. Wever R, Boer P, Hijmering M, Stroes E, Verhaar M, Kastelein J, et al. Nitric oxide production is reduced in patients with chronic renal failure. Arterioscler Thromb Vasc Biol 1999;19:1168-72. [CrossRef]

27. Rossi GP, Taddei S, Virdis A, Cavallin M, Ghiadoni L, Favilla S, et al. The T-786C and Glu298Asp polymorphisms of the endothelial nitric oxide gene affect the forearm blood flow responses of Caucasian hypertensive patients. J Am Coll Cardiol 2003;19:938-45. [CrossRef]

28. Casas JP, Bautista LE, Humphries SE, Hingorani AD. Endothelial nitric oxide synthase genotype and ischemic heart disease. Circulation 2004;109:1359-65. [CrossRef]

29. Lembo G, De Luca N, Battagli C, Iovino G, Aretini A, Musicco $\mathrm{M}$, et al. A common variant of endothelial nitric oxide synthase (Glu298Asp) is an independent risk factor for carotid atherosclerosis. Stroke 2001;32:735-40. [CrossRef]

30. Nagase S, Suzuki H, Wang Y, Kikuchi S, Hirayama A, Ueda A, et al. Association of eNOS gene polymorphisms with end stage renal diseases. Mol Cell Biochem 2003;244:113-8. [CrossRef]

31. Persu A, Stoenoiu MS, Messiaen T, Davila S, Robino C, El-Khattabi $\mathrm{O}$, et al. Modifier effect of eNOS in autosomal dominant polycystic kidney disease. Hum Mol Genet 2002;11:229-41. [CrossRef]

32. Schmidt RJ, Yokota S, Tracy TS, Sorkın MI, Baylıs C. Nitric oxide production is low in end-stage renal disease patients on peritoneal dialysis. Am J Physiol 1999:F794-7.

33. Hon WM, Lee JC, Lee KH. Effect of hemodialysis on plasma nitric oxide levels. Artif Organs 2000;24:387-90. [CrossRef]

34. Fayed HM, Kame MA, Sultan MM, Mowafy MN, Helmy SM, El-Zoghby MH. Nitric oxide generation by peripheral blood cells in chronic renal failure. Br J Biomed Sci 2002;59:24-9.

35. Rysz J, Luciak M, Kedziora J, Blaszczyk J, Sibinska E. Nitric oxide release in the peripheral blood during hemodialysis. Kidney Int 1997; 51: 294-300. [CrossRef]

36. Amore A, Bonaudo R, Ghigo D, Arese M, Costamagna C, Cirina $\mathrm{P}$, et al. Enhanced production of nitric oxide by blood-dialysis membrane interaction. J Am Soc Nephrol 1995;6:1278-83.

37. Sasaki N, Kusano E, Ootomo T, Munakata M, Shimanuki K, Ando Y, et al. Bioincompatibility of hemodialysis membranes with special reference to the changes of blood IL-6, IL-8, and nitric oxide. J Jpn Soc Dial Ther 1999;32:363-8. [CrossRef]

38. Y1lmaz E, Mir S, Berdeli A. Endothelial Nitric Oxide Synthase (eNOS) Gene Polymorphism in Early Term Chronic Allograft Nephropathy. Transplantation Proceedings 2009;41:4361-5. [CrossRef]
39. Noiri E, Satoh H, Taguchi J, Brodsky SV, Nakao A, Ogawa Y, et al. Association of eNOS Glu298Asp polymorphism with endstage renal disease. Hypertension 2002;40:535-40. [CrossRef]

40. Spoto B, Benedetto FA, Testa A, Tripepi G, Mallamaci F, Maas $\mathrm{R}$, et al. Atherosclerosis and the Glu298Asp polymorphism of the eNOS gene in white patients with end-stage renal disease. Am J Hypertens 2005;18:1549-55. [CrossRef]

41. Aras O, Hanson NQ, Bakanay SM, Tsai MY, Gulec S. Endothelial nitric oxide gene polymorphism (Glu298Asp) is not associated with coronary artery disease in Turkish population. Thromb Haemost 2002;87:347-9.

42. Dellamea BS, Pinto LC, Leitão CB, Santos KG, Canani LH. Endothelial nitric oxide synthase gene polymorphisms and risk of diabetic nephropathy: a systematic review and meta-analysis. BMC Med Genet 2014;16:1-13. [CrossRef]

43. Böger RH, Bode-Böger SM, Sydow K, Heistad DD, Lentz SR. Plasma concentration of asymmetric dimethylarginine, an endogenous inhibitor of nitric oxide synthase, is elevated in monkeys with hyperhomocyst(e)inemia or hypercholesterolemia. Arterioscler Thromb Vasc Biol 2000;20:1557-64. [CrossRef]

44. Surdacki A, Nowicki M, Sandmann J, Tsikas D, Boeger RH, Bode-Boeger SM, et al. Reduced urinary excretion of nitric oxide metabolites and increased plasma levels of asymmetrical dimethylarginine in men with essential hypertension. $J$ Cardiovasc Pharmacol 1999;33:652-8. [CrossRef]

45. Kielstein JT, Böger RH, Bode-Böger SM, Schäffer J, Barbey M, Koch KM, et al. Asymmetric dimethylarginine plasma concentrations differ in patients with endstage renal disease: relationship to treatment method and atherosclerotic disease. J Am Soc Nephrol 1999;10:594-600.

46. Hand MF, Haynes WG, Webb DJ. Hemodialysis and L-arginine, but not D-arginine, correct renal failure-associated endothelial dysfunction. Kidney Int 1998;53:1068-77. [CrossRef]

47. Kari JA, Donald AE, Vallance DT, Bruckdorfer KR, Leone A, Mullen MJ, et al. Physiology and biochemistry of endothelial function in children with chronic renal failure. Kidney Int 1997;52:468-72. [CrossRef]

48. Kielstein JT, Böger RH, Bode-Böger SM, Frölich JC, Haller H, Ritz E, et al. Marked increase of asymmetric dimethylarginine in patients with incipient primary chronic renal disease. J Am Soc Nephrol 2002;13:170-6.

49. Wahbi N, Dalton RN, Turner C, Denton M, Abbs I, Swaminathan R. Dimethylarginines in chronic renal failure. J Clin Pathol 2001;54:470-3. [CrossRef]

50. Vallance P, Leone A, Calver A, Collier J, Moncada S. Accumulation of an endogenous inhibitor of nitric oxide synthesis in chronic renal failure. Lancet 1992;339:572-5. [CrossRef]

51. Testa A, Spoto B, Tripepi G, Mallamaci F, Malatino L, Fatuzzo P, et al. The GLU298ASP variant of nitric oxide synthase interacts with asymmetric dimethyl arginine in determining cardiovascular mortality in patients with end-stage renal disease. $J$ Hypertens 2005;23:1825-30. [CrossRef]

52. Marson BP, Dickel S, Ishizawa MH, Metzger IF, Izidoro-Toledo T, da Costa BE, et al. Endothelial nitric oxide genotypes and haplotypes are not associated with end-stage renal disease. DNA Cell Biol 2011;30:55-9. [CrossRef] 